\title{
Applicability of geomechanical classifications for estimation of strength properties in Brazilian rock masses
}

\author{
TATIANA B. SANTOS, MILENE S. LANA, ALLAN E.M. SANTOS and LARISSA R.C. SILVEIRA \\ Departamento de Engenharia de Minas, Universidade Federal de Ouro Preto, \\ Rua Diogo Vasconcelos, 122, 35400-000 Ouro Preto, MG, Brazil
}

Manuscript received on February 11, 2016; accepted for publication on December 5, 2016

\begin{abstract}
Many authors have been proposed several correlation equations between geomechanical classifications and strength parameters. However, these correlation equations have been based in rock masses with different characteristics when compared to Brazilian rock masses. This paper aims to study the applicability of the geomechanical classifications to obtain strength parameters of three Brazilian rock masses. Four classification systems have been used; the Rock Mass Rating (RMR), the Rock Mass Quality (Q), the Geological Strength Index (GSI) and the Rock Mass Index (RMi). A strong rock mass and two soft rock masses with different degrees of weathering located in the cities of Ouro Preto and Mariana, Brazil; were selected for the study. Correlation equations were used to estimate the strength properties of these rock masses. However, such correlations do not always provide compatible results with the rock mass behavior. For the calibration of the strength values obtained through the use of classification systems, stability analyses of failures in these rock masses have been done. After calibration of these parameters, the applicability of the various correlation equations found in the literature have been discussed. According to the results presented in this paper, some of these equations are not suitable for the studied rock masses.
\end{abstract}

Key words: geomechanical classifications, rock slopes, stability analyses, strength properties of rock masses.

\section{INTRODUCTION}

Rock masses are made of intact rocks and discontinuities. In order to quantify the quality of rock masses, several authors have proposed geomechanical classifications systems, like the RMR (Bieniawski 1989), the Q system (Barton et al. 1974), the GSI (Hoek 1994) and the RMi (Palmström 1995). They are important tools, widely

Correspondence to: Tatiana Barreto dos Santos

E-mail: tati.barreto12@gmail.com used by geotechnical engineers for estimation of rock mass and discontinuity properties. Knowledge of these strength properties is essential to predict failures in urban, roadway and mining slopes.

Besides the geomechanical classifications, stability analysis is also a good tool for estimating mechanical properties of rock masses. Through this analyses, it is possible to reproduce the conditions at the time of failure, once the factor of safety (FS $=1)$ is known. 
Stability analysis methods have been thoroughly researched. They present reliable results and generally represent what really occurs in rock masses. However, they depend on strength properties of rock masses. The knowledge of strength properties by in situ tests is highly relevant, but difficulties associated with sampling and execution of them precludes their use, leading to the employment of indirect methods, like the geomechanical classifications.

Many authors have been proposed several correlation equations between the classifications and strength parameters. They are presented in this paper. However, these correlation equations have been proposed for rock masses with different characteristics when compared to Brazilian rock masses. This paper aims to study the applicability of the geomechanical classifications to obtain strength parameters of three Brazilian rock masses.

Three rock slopes were selected in the cities of Ouro Preto and Mariana in Minas Gerais province, Brazil. Geological and geotechnical survey and geomechanical classification of the rock masses were carried out. Strength parameters of these rock masses were estimated based on geomechanical classifications. The stability analyses of failures were used for calibration of the rock mass parameters given by correlation equations. Rock masses with different lithologies and characteristics were selected for this study in order to test the applicability of the geomechanical classifications to obtain strength properties in different cases.

\section{MATERIALS AND METHODS}

\section{GEOLOGICAL AND GEOTECHNICAL SURVEY}

The geological and geotechnical surveys were done in two slopes excavated in schists and in a hill consisted of quartzite. They were performed basically in two stages. In the first stage, study of the geological context and observation of petrographic features on hand samples have been done.
Geological maps of the area, on a scale of 1:25000, were used in this study. In the second stage the geotechnical survey of the discontinuities has been carried out. In this stage, survey of the spacing, persistence, opening, roughness and weathering were made in outcrops with easy access. Spacing and opening were measured with tapes. Persistence was estimated through observations in the outcrops. Roughness was estimated based on the roughness profiles proposed by Barton (1978). Weathering was estimated based on a table proposed by ISRM (1981), witch correlates de degree of weathering with the characteristics of the rock mass.

\section{INTACT ROCK STRENGTH}

Three types of tests to measure the intact rock strength were done: point load test, geological hammer test and Schmidt rebound test. Samples yielded by drills were not available in the sites, precluding the execution of uniaxial compression tests.

Point load tests were performed as recommended by ISRM (2007). Samples were cut parallel and perpendicular to the foliation. The load value at the time of the failure $(\mathrm{P})$ and the distance between the two conical platens $\left(\mathrm{D}_{\mathrm{e}}\right)$ were taken. The point load index (Is) and the point load index adjusted for samples with $50 \mathrm{~mm}\left(\mathrm{Is}_{(50)}\right)$ were obtained from equations (1) and (2). Equations (3) and (4), proposed by Singh and Singh (1993) and Basu and Kamran (2010), were used to estimate the uniaxial compressive strength $(\sigma c)$ from point load test in quartzites and schists, respectively.

$$
\begin{aligned}
& I S=\frac{P}{D_{e}^{2}} \\
& I S_{(50)}=\left(\frac{D_{e}}{50}\right)^{0.45} \times I S \\
& \sigma \mathrm{c}=23.4 \times I S_{(50)}
\end{aligned}
$$


$\sigma c=11.103 . I s_{(50)}+37.659$

In case of the schists, the sampling of rock mass to perform the strength tests was possible. However, in case of the quartzite the sampling was not possible due to the high strength of the rock. Therefore, rock samples which have been located at the toe of the slope were used.

Geological hammer tests were performed as usual. Rock masses tested with geological hammer were classified as R0 (very soft rocks) to R6 (extremely strong rocks), according to ISRM (1981).

Schmidt rebound tests were performed according to ASTM (2001). Schmidt hammer type $\mathrm{N}$ was used. For a good result it is necessary to find a fresh rock outcrop, sand the surface and apply the Schmidt hammer perpendicularly to the sanded surface. The tests were performed at regular intervals considering a scanline along the outcrop. Then, the equation (5), proposed by Shalabi et al. (2007), was chosen for estimating the uniaxial compressive strength in schists. Equation (6), proposed by Aydin and Basu (2005), was needed to find values through.

$\sigma c=3.201 R_{L}-46.59$

$R_{L}=\frac{R_{N}-3.3673}{1.064}$

Where:

$\sigma c$ is the uniaxial compressive strength;

$\mathrm{R}_{\mathrm{L}}$ is the rebound value obtained by Schmidt hammer type L;

$\mathrm{R}_{\mathrm{N}}$ is the rebound value obtained by Schmidt hammer type $\mathrm{N}$.

Equations for estimating the uniaxial compressive strength for quartzite have not been found in the literature. Equations for other lithology types have not yielded coherent results.
APPLICATION OF THE GEOMECHANICAL CLASSIFICATION SYSTEMS

RMR, Q, GSI and RMi systems were applied to the studied slopes. Since the geomechanical classifications were used to estimate the strength parameters of the studied rock masses, the basic RMR and the basic Q index were used. This is recommended by the authors of the classification systems. Basic RMR is based on five parameters, which are the uniaxial compressive strength, RQD, spacing, condition of discontinuities and the maximum value for groundwater parameter. The system proposed by Bieniawski (1989) is the most used geomechanical classification in the world. Basic Q index was proposed by Barton et al. (1974) and it is based on the follow parameters: RQD, joint set number $\left(\mathrm{J}_{\mathrm{n}}\right)$, joint roughness number $\left(\mathrm{J}_{\mathrm{r}}\right)$ and joint alteration number $\left(\mathrm{J}_{\mathrm{a}}\right)$. GSI is based on a visual assessment of the characteristics of rock mass. The structure and the quality of the surface of the rock mass are evaluated.

Although the RMi system has not been widely used, it seems to be based on field straightforward parameters and it was used in this paper. It is calculated by the product of the uniaxial compressive strength of intact rock and a reduction factor of strength (jointing parameter, JP) that represents the effects of discontinuities on the strength of rock masses. JP is a combination of block size, measured in terms of its volume $\left(\mathrm{V}_{\mathrm{b}}\right)$, and the joint condition factor $\left(\mathrm{J}_{\mathrm{c}}\right)$. JP is equal to 1 when the rock is intact and equal to 0 when the rock is completely fractured.

APPLICATION OF THE CORRELATION EQUATIONS TO ESTIMATE STRENGTH PARAMETERS IN ROCK MASSES

There are many correlation equations between classification systems and mechanical parameters in the literature. These equations were used to estimate the mechanical parameters in the studied rock masses. Bieniawski (1989) proposed ranges 
of cohesion and friction angle for rock masses, according to RMR values. They are presented in Table I.

Many other authors have proposed correlation equations between geomechanical classification systems and strength properties of rock masses. The most commonly used equations were applied in this study. They are shown in Table II.

\section{APPLICATION OF THE BARTON-BANDIS CRITERION}

A criterion for determining discontinuity shear strength was proposed by Barton and Bandis (1982), to take into account the roughness of discontinuities. This criterion was used in one of the studied slopes because it yielded reliable results comparing to other criteria. It is presented in Equation (7).

$$
\tau=\sigma \tan \left(J R C \log _{10}\left(\frac{J C S}{\sigma}\right)+\varnothing_{r}\right)
$$

Where:

JRC is the joint roughness coefficient;

JCS is the joint wall compressive strength;

pr is the residual friction angle.

In this study, JRC was obtained by an abacus proposed by Barton and Bandis (1982), which relates the amplitude of discontinuity to the length of its measured profile. JCS is the joint wall compressive strength, which was obtained through RMi.

\section{STABILITY ANALYSES FOR CALIBRATION OF STRENGTH PARAMETERS}

Stability analyses were used in this study to calibrate the strength parameters obtained from the geomechanical classifications. Rocscience software were used in these analyses. Deterministic stability analyses were performed. The selection of the software for stability analyses was made based on failures that had already occurred in the studied rock masses. The software used, with their characteristics and applications, were presented below.

Slide v. 6.0: Slide is a 2D slope stability program for evaluating the safety factor or probability of failure, of circular or non-circular failure surfaces in soil or rock slopes. Slide is very simple to use, and yet complex models can be created and analyzed quickly and easily. External loading, groundwater and support can all be modeled in a variety of ways (Rocscience Inc. 2010).

Swedge v. 6.0: Swedge is a quick, interactive and simple to use analysis tool for evaluating the geometry and stability of surface wedges in rock slopes. Wedges are defined by two (or three) intersecting discontinuity planes, the slope surface and an optional tension crack (Rocscience Inc. 2006).

RocTopple v. 1.0: RocTopple is an interactive software tool for performing toppling analysis and support design of rock slopes. The analysis is based on the popular limit equilibrium block toppling method of Goodman and Bray first published in a paper, Toppling of Rock Slopes, in 1976 (Rocscience Inc. 2014).

All the software used in this study are based on limit equilibrium analysis and solutions proposed by experts, that published their methodologies in the literature.

\section{RESULTS}

\section{CHARACTERIZATION OF THE STUDIED ROCK MASSES}

The first slope (TLD-01) studied is located in Cabanas neighborhood, Mariana city. The region is an irregular settlement. Rock block falls are a common occurrence in this site. The entire slope is 275 meters in length and has variable height. Its geographical coordinates are $20^{\circ} 24^{\prime} 2.15^{\prime \prime}$ and $43^{\circ} 25^{\prime} 6.68^{\prime \prime} \mathrm{W}$. An outcrop which is 30 meters in length and with average height of 47 meters was selected. This outcrop has selected because of its 
accessibility and the ease to perform data survey. The TLD-01 slope can be seen in Figure 1, which shows the high vulnerability situation of residences below it.

The outcrop of TLD-01 was split in five sectors, for taking into account the different geomechanical behavior observed when data from geotechnical survey were analyzed.

The second slope (TLD-02) is located on the railway which connects the cities of Ouro Preto and Mariana. It is 9 meters high, with a dip of $89^{\circ}$ and geographical coordinates of $20^{\circ} 23^{\prime} 34.8^{\prime \prime} \mathrm{S} 43^{\circ} 29^{\prime}$ 58.3" W. This rock mass has apparently regular quality and high degree of fracturing. Rock blocks forming a stepped base can be seen, although toppling failure was not identified in this site. Maybe toppling failure has been occurred during the slope excavation due to blasting. The TLD-02 slope is shown in Figure 1.

The third slope (TLD-03) studied is located on the Inconfidentes's highway near the $\mathrm{km} 88$. The slope was split in two sectors, since they have different geomechanical characteristics. Sector 1 has high degree of fracturing and weathering, 100 meters in length, two benches of approximately 15 and 20 meters in length and a berm of 2 meters wide. Sector 2 presents low degree of weathering and fracturing. TLD-03 slope is shown in Figure 1.

\section{GEOLOGICAL AND GEOTECHNICAL DATA}

The geological and geotechnical data were surveyed as described in the methodology. Average values for each parameter evaluated in field were considered. Table III shows the geological and geotechnical data for the three slopes studied and Tables IV, V and VI show the characteristics of the discontinuities for TLD-01, TLD-02 and TLD-03, respectively.

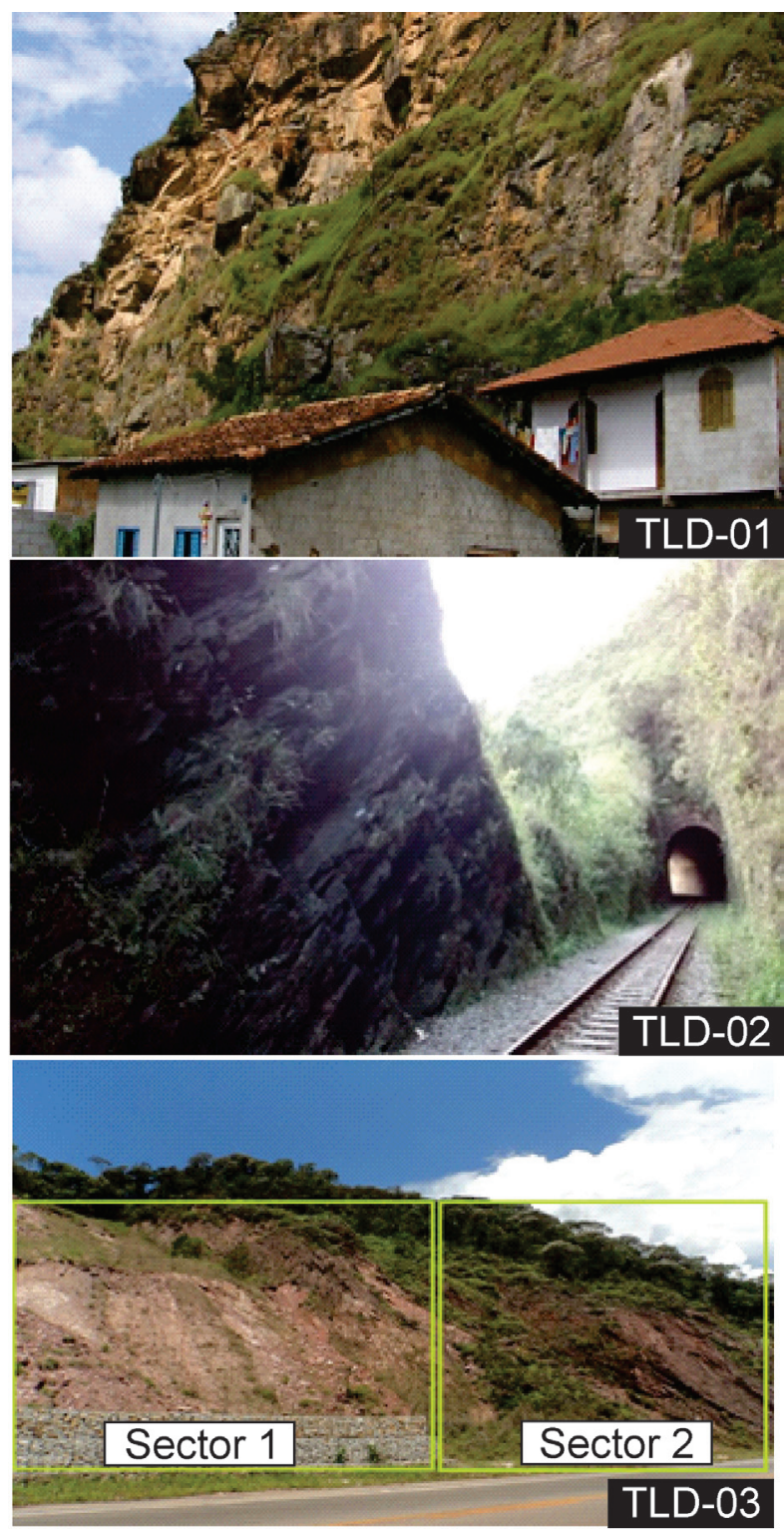

Figure 1 - Studied slopes.

TABLE I

Correlation between RMR classes and strength parameters of rock masses (Bieniawski 1989).

\begin{tabular}{lccccc}
\hline RMR class & I & II & III & IV & V \\
\hline $\begin{array}{l}\text { Cohesion } \\
(\mathrm{KPa})\end{array}$ & $>400$ & $300-400$ & $\begin{array}{c}200- \\
300\end{array}$ & $100-200$ & $<100$ \\
$\begin{array}{l}\text { Friction } \\
\text { angle }\left({ }^{\circ}\right)\end{array}$ & $>45$ & $35-45$ & $25-35$ & $15-25$ & $<15$ \\
\hline
\end{tabular}


TABLE II

Correlation equations between geomechanical classifications and mechanical properties of rock masses and discontinuities.

\begin{tabular}{|c|c|c|}
\hline Parameter & Author & Correlation equations \\
\hline \multirow{2}{*}{$\begin{array}{l}\text { Hoek and Brown } \\
\text { parameters }\end{array}$} & $\begin{array}{l}\text { Hoek et al. } \\
\text { (2002) }\end{array}$ & $\begin{array}{c}m_{b}=m_{i} \times e^{\frac{G S I-100}{28-14 D}} \quad S=e^{\frac{G S I-100}{9-3 D}} \\
a=\frac{1}{2}+\frac{1}{6}\left(e^{-\frac{G S I}{15}}-e^{-\frac{20}{3}}\right)\end{array}$ \\
\hline & $\begin{array}{l}\text { Palmström } \\
\text { (1996) }\end{array}$ & $\begin{array}{c}m_{b}=m_{i} J P^{0.64} \quad \text { (not disturbed rock mass) } \\
m_{b}=m_{i} J P^{0.857} \quad \text { (disturbed rock mass) } \\
s=J P^{2} \quad a=0.5\end{array}$ \\
\hline $\begin{array}{l}\text { Cohesion (c) and friction } \\
\text { angle of rock mass }(\phi)\end{array}$ & $\begin{array}{l}\text { Hoek et al. } \\
\text { (2002) }\end{array}$ & $\begin{array}{c}c=\frac{\sigma_{c}\left[(1+2 a) s+(1-a) m_{b} \cdot \sigma_{3 n}\right]\left(s+m_{b} \cdot \sigma_{3 n}\right)^{a-1}}{(1+a)(2+a) \sqrt{1+\left[6 a \cdot m_{b}\left(s+m_{b} \cdot \sigma_{3 n}\right)^{a-1}\right] /[(1+a)(2+a)]}} \\
\varnothing=\sin ^{-1}\left[\frac{6 \cdot a \cdot m_{b}\left(s+m_{b} \cdot \sigma_{3 n}\right)^{a-1}}{2(1+a)(2+a)+6 \cdot a \cdot m_{b}\left(s+m_{b} \cdot \sigma_{3 n}\right)^{a-1}}\right] \\
\frac{\sigma_{3 \max }}{\sigma_{c}}=0,47\left(\frac{\sigma_{c}}{\gamma H}\right)^{-0,94}\end{array}$ \\
\hline Cohesion of rock mass (c) & & $c=\frac{R Q D}{J n} \times \frac{1}{S R F} \times \frac{\sigma_{c}}{100}$ \\
\hline $\begin{array}{l}\text { Friction angle of } \\
\text { discontinuity }(\phi r)\end{array}$ & Barton (2002) & $\varnothing_{r}=\tan ^{-1}\left(\frac{J r}{J a}\right)$ \\
\hline
\end{tabular}

Where, $m_{b}$ is a reduced value of the material constant $m_{i} ; s$ and are $a$ constants for the rock mass; $J P$ is the joint parameter obtained by RMi; $\sigma_{c}$ is the uniaxial compressive strength of the intact rock; $\gamma$ is the unit weight; $H$ is the height of the slope and $\sigma_{3 n}$ is defined by expression: $\frac{\sigma_{\max }}{\sigma_{c}}$ and $S R F$ (stress reduction factor) $=1$.

TABLE III

Geological and geotechnical data for the three studied slopes.

\begin{tabular}{|c|c|c|c|c|c|c|}
\hline \multirow{2}{*}{ Slope } & \multirow{2}{*}{ Mineralogy } & \multirow{2}{*}{ Petrography } & \multirow{2}{*}{$\begin{array}{c}\text { Slope } \\
\text { (Dip/Dip direction) }\end{array}$} & \multicolumn{3}{|c|}{ Discontinuities (Dip/Dip direction) } \\
\hline & & & & Family 1 & Family 2 & Family 3 \\
\hline TLD-01 & $\begin{array}{l}\text { Quartz, biotite, } \\
\text { muscovite }\end{array}$ & Quartzite & $82 / 137$ & $22 / 324$ & $62 / 221$ & $59 / 159$ \\
\hline TLD-02 & $\begin{array}{c}\text { Quartz, chlorite, } \\
\text { muscovite }\end{array}$ & $\begin{array}{l}\text { Quartz-chlorite- } \\
\text { muscovite-schist }\end{array}$ & $88 / 259$ & $37 / 195$ & $46 / 139$ & $49 / 042$ \\
\hline TLD-03 & $\begin{array}{c}\text { Quartz, chlorite, } \\
\text { muscovite }\end{array}$ & $\begin{array}{l}\text { Quartz-chlorite- } \\
\text { muscovite-schist }\end{array}$ & $55 / 215$ & $68 / 267$ & $82 / 204$ & $47 / 198$ \\
\hline
\end{tabular}


TABLE IV

Characteristics of the discontinuities of the TLD-01.

\begin{tabular}{|c|c|c|c|c|c|c|c|c|}
\hline Slope & Sector & Family & $\begin{array}{l}\text { Spacing } \\
\text { (cm) }\end{array}$ & $\begin{array}{c}\text { Opening } \\
(\mathrm{mm})\end{array}$ & $\begin{array}{c}\text { Persistence } \\
\text { (m) }\end{array}$ & Roughness & $\begin{array}{l}\text { Infilling } \\
\text { (gouge) }\end{array}$ & Weathering \\
\hline & & 1 & 26 & 1 to 5 & 20 & $\begin{array}{l}\text { Roughness } \\
\text { (planar) }\end{array}$ & $\begin{array}{l}\text { soft gouge } \\
<5 \mathrm{~mm}\end{array}$ & $\begin{array}{c}\text { Slightly } \\
\text { weathered }\end{array}$ \\
\hline & 1 & 2 & 104 & 20 to 100 & 5 & $\begin{array}{l}\text { Roughness } \\
\text { (undulating) }\end{array}$ & None & Unweathered \\
\hline & & 3 & 70 & 10 to 50 & 5 & $\begin{array}{l}\text { Roughness } \\
\text { (undulating) }\end{array}$ & $\begin{array}{l}\text { soft gouge } \\
\quad<5 \mathrm{~mm}\end{array}$ & Unweathered \\
\hline & & 1 & 40 & 1 to 5 & 20 & $\begin{array}{l}\text { Roughness } \\
\text { (planar) }\end{array}$ & $\begin{array}{l}\text { soft gouge } \\
<5 \mathrm{~mm}\end{array}$ & $\begin{array}{c}\text { Slightly } \\
\text { weathered }\end{array}$ \\
\hline & 2 & 2 & 150 & 20 to 100 & 5 & $\begin{array}{l}\text { Roughness } \\
\text { (undulating) }\end{array}$ & None & Unweathered \\
\hline & & 3 & 60 & 10 to 50 & 5 & $\begin{array}{l}\text { Roughness } \\
\text { (undulating) }\end{array}$ & $\begin{array}{l}\text { soft gouge } \\
<5 \mathrm{~mm}\end{array}$ & $\begin{array}{c}\text { Slightly } \\
\text { weathered }\end{array}$ \\
\hline & & 1 & 29 & 1 to 5 & 20 & $\begin{array}{l}\text { Roughness } \\
\text { (planar) }\end{array}$ & $\begin{array}{l}\text { soft gouge } \\
<5 \mathrm{~mm}\end{array}$ & $\begin{array}{c}\text { Slightly } \\
\text { weathered }\end{array}$ \\
\hline \multirow[t]{8}{*}{$\begin{array}{l}\text { TLD- } \\
01\end{array}$} & 3 & 2 & 130 & 20 to 100 & 5 & $\begin{array}{l}\text { Roughness } \\
\text { (undulating) }\end{array}$ & None & Unweathered \\
\hline & & 3 & 56 & 10 to 50 & 5 & $\begin{array}{l}\text { Roughness } \\
\text { (undulating) }\end{array}$ & $\begin{array}{l}\text { soft gouge } \\
\quad<5 \mathrm{~mm}\end{array}$ & $\begin{array}{c}\text { Slightly } \\
\text { weathered }\end{array}$ \\
\hline & & 1 & 74 & 1 to 5 & 20 & $\begin{array}{l}\text { Roughness } \\
\text { (planar) }\end{array}$ & $\begin{array}{l}\text { soft gouge } \\
<5 \mathrm{~mm}\end{array}$ & Unweathered \\
\hline & 4 & 2 & 201 & 20 to 100 & 5 & $\begin{array}{l}\text { Roughness } \\
\text { (undulating) }\end{array}$ & None & Unweathered \\
\hline & & 3 & 122 & 10 to 50 & 5 & $\begin{array}{l}\text { Roughness } \\
\text { (undulating) }\end{array}$ & $\begin{array}{l}\text { soft gouge } \\
<5 \mathrm{~mm}\end{array}$ & Unweathered \\
\hline & & 1 & 42 & 1 to 5 & 20 & $\begin{array}{l}\text { Roughness } \\
\text { (planar) }\end{array}$ & $\begin{array}{l}\text { soft gouge } \\
\quad<5 \mathrm{~mm}\end{array}$ & $\begin{array}{c}\text { Slightly } \\
\text { weathered }\end{array}$ \\
\hline & 5 & 2 & 134 & 20 to 100 & 5 & $\begin{array}{l}\text { Roughness } \\
\text { (undulating) }\end{array}$ & None & Unweathered \\
\hline & & 3 & 71 & 10 to 50 & 5 & $\begin{array}{l}\text { Roughness } \\
\text { (undulating) }\end{array}$ & $\begin{array}{l}\text { soft gouge } \\
\quad<5 \mathrm{~mm}\end{array}$ & $\begin{array}{l}\text { Slightly } \\
\text { weathered }\end{array}$ \\
\hline
\end{tabular}

TABLE V

Characteristics of the discontinuities of the TLD-02.

\begin{tabular}{|c|c|c|c|c|c|c|c|c|}
\hline Slope & Sector & Family & $\begin{array}{l}\text { Spacing } \\
(\mathrm{cm})\end{array}$ & $\begin{array}{l}\text { Opening } \\
\text { (mm) }\end{array}$ & $\begin{array}{c}\text { Persistence } \\
\text { (m) }\end{array}$ & Roughness & $\begin{array}{l}\text { Infilling } \\
\text { (gouge) }\end{array}$ & Weathering \\
\hline \multirow{3}{*}{ TLD-02 } & \multirow{3}{*}{-} & 1 & 25 & $<0.1$ & 15 & $\begin{array}{c}\text { Smooth } \\
\text { (undulating) }\end{array}$ & $\begin{array}{l}\text { soft gouge } \\
<5 \mathrm{~mm}\end{array}$ & $\begin{array}{c}\text { Slightly } \\
\text { weathered }\end{array}$ \\
\hline & & 2 & 42 & 0.1 to 1 & 10 & $\begin{array}{c}\text { Slightly } \\
\text { roughness } \\
\text { (undulating) }\end{array}$ & $\begin{array}{l}\text { soft gouge } \\
<5 \mathrm{~mm}\end{array}$ & $\begin{array}{c}\text { Slightly } \\
\text { weathered }\end{array}$ \\
\hline & & 3 & 38 & 0.1 to 1 & 10 & $\begin{array}{c}\text { Slightly } \\
\text { roughness } \\
\text { (undulating) }\end{array}$ & None & $\begin{array}{c}\text { Slightly } \\
\text { weathered }\end{array}$ \\
\hline
\end{tabular}


TABLE VI

Characteristics of the discontinuities of the TLD-03.

\begin{tabular}{|c|c|c|c|c|c|c|c|c|}
\hline Slope & Sector & Family & $\begin{array}{l}\text { Spacing } \\
\text { (cm) }\end{array}$ & $\begin{array}{l}\text { Opening } \\
(\mathrm{mm})\end{array}$ & $\begin{array}{c}\text { Persistence } \\
\text { (m) }\end{array}$ & Roughness & $\begin{array}{l}\text { Infilling } \\
\text { (gouge) }\end{array}$ & Weathering \\
\hline \multirow{6}{*}{ TLD-03 } & \multirow{3}{*}{1} & 1 & 10.5 & 0.1 to 1 & 10 & $\begin{array}{l}\text { Slightly roughness } \\
\text { (undulating) }\end{array}$ & $\begin{array}{l}\text { soft gouge } \\
<5 \mathrm{~mm}\end{array}$ & $\begin{array}{l}\text { Highly } \\
\text { weathered }\end{array}$ \\
\hline & & 2 & 10.5 & 0.1 to 1 & 10 & $\begin{array}{l}\text { Roughness } \\
\text { (undulating) }\end{array}$ & $\begin{array}{l}\text { soft gouge } \\
<5 \mathrm{~mm}\end{array}$ & $\begin{array}{c}\text { Highly } \\
\text { weathered }\end{array}$ \\
\hline & & 3 & 10.5 & $<0.1$ & 20 & Smooth (planar) & $\begin{array}{l}\text { soft gouge } \\
<5 \mathrm{~mm}\end{array}$ & $\begin{array}{c}\text { Highly } \\
\text { weathered }\end{array}$ \\
\hline & \multirow{3}{*}{2} & 1 & 120 & 0.1 to 1 & 10 & $\begin{array}{l}\text { Slightly roughness } \\
\text { (undulating) }\end{array}$ & $\begin{array}{l}\text { soft gouge } \\
<5 \mathrm{~mm}\end{array}$ & $\begin{array}{c}\text { Slightly } \\
\text { weathered }\end{array}$ \\
\hline & & 2 & 100 & 0.1 to 1 & 10 & $\begin{array}{l}\text { Slightly roughness } \\
\text { (undulating) }\end{array}$ & $\begin{array}{l}\text { soft gouge } \\
<5 \mathrm{~mm}\end{array}$ & $\begin{array}{c}\text { Slightly } \\
\text { weathered }\end{array}$ \\
\hline & & 3 & 10.5 & $<0.1$ & 20 & Smooth (undulating) & $\begin{array}{c}\text { soft gouge } \\
<5 \mathrm{~mm}\end{array}$ & $\begin{array}{c}\text { Slightly } \\
\text { weathered }\end{array}$ \\
\hline
\end{tabular}

\section{STRENGTH TESTS IN INTACT ROCK}

Three types of strength tests were made to obtain the uniaxial compressive strength. In case of the point load and Schmidt rebound tests, correlation equations were used to obtain the uniaxial compressive strength, according to the lithology. Table VII shows the uniaxial compressive strength obtained for TLD-01, TLD-02 and TLD-03.

The same value of point load test in TLD-01 was considered because loosen blocks available at the site were used for the tests. The samples were prepared using these blocks, according to the recommendations of ISRM (2007).

\section{GEOMECHANICAL CLASSIFICATIONS}

Rock masses are classified according to RQD, RMR, Q, GSI and RMi. In case of the RQD, it was obtained using equation proposed by Palmström (1982). In other classifications systems, the discontinuity in the worst condition was used to obtain the indices. The results are shown in Table VIII.

\section{MECHANICAL PROPERTIES OF ROCK MASSES}

There are several correlation equations between the geomechanical classifications and strength
TABLE VII

Uniaxial compressive strength obtained for TLD-01, TLD02 and TLD-03.

\begin{tabular}{lcccc}
\hline Slope & Sector & $\begin{array}{c}\text { Point } \\
\text { load } \\
\text { test }\end{array}$ & $\begin{array}{c}\text { Geological } \\
\text { hammer test }\end{array}$ & $\begin{array}{c}\text { Schmidt } \\
\text { hammer } \\
\text { test }\end{array}$ \\
\hline & 1 & & 50 to $100 \mathrm{MPa}$ & \\
& 2 & & 100 to $250 \mathrm{MPa}$ & \\
TLD-01 & 3 & 90.16 & 50 to $100 \mathrm{MPa}$ & - \\
& 4 & $\mathrm{MPa}$ & 100 to $250 \mathrm{MPa}$ & \\
& 5 & & 100 to $250 \mathrm{MPa}$ & \\
\hline TLD-02 & - & 38.39 & 25 to $50 \mathrm{MPa}$ & 27.01 \\
& 1 & - & 1 to $5 \mathrm{MPa}$ & 24.88 \\
\hline TLD-03 & & & & $\mathrm{MPa}$ \\
& 2 & - & 5 to $25 \mathrm{MPa}$ & $\begin{array}{c}33.92 \\
\mathrm{MPa}\end{array}$ \\
\hline
\end{tabular}

properties of the rock masses, as discussed before. The values obtained by these correlation equations are shown in Table IX.

\section{BARTON AND BANDIS CRITERION}

The parameters of the Barton and Bandis criterion were obtained for the toppling discontinuity (family 3 ) and the basal discontinuity (family 1) of the TLD-02. JRC is 12, for both families. JCS was obtained by RMi and it corresponds to the uniaxial compressive strength of the rock mass. Its value is 
TABLE VIII

Geomechanical classification of the TLD-01, TLD-02 and TLD-03.

\begin{tabular}{|c|c|c|c|c|c|c|}
\hline Slope & Sector & RQD & RMR & Q & GSI & RMi (MPa) \\
\hline \multirow{10}{*}{ TLD-01 } & \multirow{2}{*}{1} & $94.4 \%$ & 68 & 15.7 & \multirow{2}{*}{67 to 72} & 11.7 \\
\hline & & Excellent & Good & Good & & Extremely strong \\
\hline & \multirow{2}{*}{2} & $91.6 \%$ & 69 & 16.5 & \multirow{2}{*}{67 to 72} & 18 \\
\hline & & Excellent & Good & Good & & Extremely strong \\
\hline & \multirow{2}{*}{3} & $93.8 \%$ & 62 & 15.9 & \multirow{2}{*}{67 to 72} & 12.6 \\
\hline & & Excellent & Good & Good & & Extremely strong \\
\hline & \multirow{2}{*}{4} & $92.7 \%$ & 73 & 16.7 & \multirow{2}{*}{67 to 72} & 39 \\
\hline & & Excellent & Good & Good & & Extremely strong \\
\hline & \multirow{2}{*}{5} & $96.3 \%$ & 72 & 16.7 & \multirow{2}{*}{67 to 72} & 18 \\
\hline & & Excellent & Good & Good & & Extremely strong \\
\hline \multirow{2}{*}{ TLD-02 } & \multirow{2}{*}{-} & \multirow{2}{*}{$85.2 \%$ Good } & 60 & 6.3 & \multirow{2}{*}{60 to 70} & 3.8 \\
\hline & & & Fair & Regular & & Strong \\
\hline \multirow{4}{*}{ TLD-03 } & \multirow{2}{*}{1} & \multirow{2}{*}{$20.7 \%$ Very poor } & 37 & 1.2 & \multirow{2}{*}{15 to 25} & 0.008 \\
\hline & & & Poor & Poor & & Weak \\
\hline & \multirow{2}{*}{2} & \multirow{2}{*}{$77.8 \%$ Good } & 54 & 5.7 & \multirow{2}{*}{40 to 50} & 0.9 \\
\hline & & & Fair & Fair & & Moderate \\
\hline
\end{tabular}

TABLE IX

Strength parameters.

\begin{tabular}{|c|c|c|c|c|c|c|}
\hline Slope & Sector & $\begin{array}{l}\text { Cohesion and } \\
\text { friction angle of } \\
\text { the rock mass by } \\
\text { Bieniawski (1989) }\end{array}$ & $\begin{array}{c}\text { Cohesion } \\
\text { of the rock } \\
\text { mass by } \\
\text { Barton } \\
(2002)\end{array}$ & $\begin{array}{l}\text { Discontinuity friction } \\
\text { angle by Barton } \\
(2002)\end{array}$ & $\begin{array}{l}\text { Parameters of the } \\
\text { Hoek and Brown } \\
\text { criterion by Hoek et } \\
\text { al. (2002) }\end{array}$ & $\begin{array}{c}\text { Parameters of } \\
\text { the Hoek and } \\
\text { Brown criterion by } \\
\text { Palmström (1996) }\end{array}$ \\
\hline \multirow{5}{*}{ TLD-01 } & 1 & & $9.4 \mathrm{MPa}$ & $\begin{array}{l}\left.56^{\circ} \text { (family } 1\right) \\
\left.72^{\circ} \text { (family } 2\right) \\
\left.72^{\circ} \text { (family } 3\right)\end{array}$ & \multirow{5}{*}{$\begin{array}{c}\mathrm{m}_{\mathrm{b}}=6.85 \\
\mathrm{~s}=0.036 \\
\mathrm{a}=0.501 \\
\mathrm{c}=2.548 \mathrm{MPa} \\
\phi=64^{\circ}\end{array}$} & $\begin{array}{c}\mathrm{m}_{\mathrm{b}}=5.42 \\
\mathrm{~s}=0.0169 \\
\mathrm{a}=0.5 \\
\mathrm{c}=1.4 \mathrm{MPa} \\
\phi=61^{\circ}\end{array}$ \\
\hline & 2 & & $13.2 \mathrm{MPa}$ & $\begin{array}{l}\left.56^{\circ} \text { (family } 1\right) \\
\left.72^{\circ} \text { (family } 2\right) \\
\left.72^{\circ} \text { (family } 3\right)\end{array}$ & & $\begin{array}{c}\mathrm{m}_{\mathrm{b}}=5.93 \\
\mathrm{~s}=0.0225 \\
\mathrm{a}=0.5 \\
\mathrm{c}=2.0 \mathrm{MPa} \\
\phi=63^{\circ}\end{array}$ \\
\hline & 3 & $\begin{array}{c}300 \text { to } 400 \mathrm{MPa} \\
35^{\circ} \text { to } 45^{\circ}\end{array}$ & $9.6 \mathrm{MPa}$ & $\begin{array}{l}\left.56^{\circ} \text { (family } 1\right) \\
\left.72^{\circ} \text { (family } 2\right) \\
\left.72^{\circ} \text { (family } 3\right)\end{array}$ & & $\begin{array}{c}\mathrm{m}_{\mathrm{b}}=5.68 \\
\mathrm{~s}=0.0196 \\
\mathrm{a}=0.5 \\
\mathrm{c}=1.5 \mathrm{MPa} \\
\phi=62^{\circ}\end{array}$ \\
\hline & 4 & & 16.7 MPa & $\begin{array}{l}\left.63^{\circ} \text { (family } 1\right) \\
\left.72^{\circ} \text { (family } 2\right) \\
\left.72^{\circ} \text { (family } 3\right)\end{array}$ & & $\begin{array}{c}\mathrm{m}_{\mathrm{b}}=8.45 \\
\mathrm{~s}=0.0676 \\
\mathrm{a}=0.5 \\
\mathrm{c}=4.2 \mathrm{MPa} \\
\phi=64^{\circ}\end{array}$ \\
\hline & 5 & & $13.3 \mathrm{MPa}$ & $\begin{array}{l}\left.56^{\circ} \text { (family } 1\right) \\
\left.72^{\circ} \text { (family } 2\right) \\
\left.72^{\circ} \text { (family } 3\right)\end{array}$ & & $\begin{array}{c}\mathrm{m}_{\mathrm{b}}=5.93 \\
\mathrm{~s}=0.0225 \\
\mathrm{a}=0.5 \\
\mathrm{c}=2.0 \mathrm{MPa} \\
\phi=63^{\circ}\end{array}$ \\
\hline
\end{tabular}


TABLE IX (continuation)

\begin{tabular}{|c|c|c|c|c|c|c|}
\hline Slope & Sector & $\begin{array}{l}\text { Cohesion and } \\
\text { friction angle of } \\
\text { the rock mass by } \\
\text { Bieniawski (1989) }\end{array}$ & $\begin{array}{l}\text { Cohesion } \\
\text { of the rock } \\
\text { mass by } \\
\text { Barton } \\
(2002)\end{array}$ & $\begin{array}{l}\text { Discontinuity friction } \\
\text { angle by Barton } \\
(2002)\end{array}$ & $\begin{array}{l}\text { Parameters of the } \\
\text { Hoek and Brown } \\
\text { criterion by Hoek et } \\
\text { al. (2002) }\end{array}$ & $\begin{array}{c}\text { Parameters of } \\
\text { the Hoek and } \\
\text { Brown criterion by } \\
\text { Palmström (1996) }\end{array}$ \\
\hline TLD-02 & 1 & $\begin{array}{c}200 \text { to } 300 \mathrm{KPa} \\
25^{\circ} \text { to } 35^{\circ}\end{array}$ & $25.5 \mathrm{MPa}$ & $\begin{array}{l}\left.35^{\circ} \text { (family } 1\right) \\
\left.45^{\circ} \text { (family } 2\right) \\
\left.45^{\circ} \text { (family } 3\right)\end{array}$ & $\begin{array}{c}\mathrm{m}_{\mathrm{b}}=3.43 \\
\mathrm{~s}=0.02 \\
\mathrm{a}=0.502 \\
\mathrm{c}=0.482 \mathrm{MPa} \\
\phi=60^{\circ}\end{array}$ & $\begin{array}{c}\mathrm{m}_{\mathrm{b}}=3.41 \\
\mathrm{~s}=0.02 \\
\mathrm{a}=0.5 \\
\mathrm{c}=0.483 \mathrm{MPa} \\
\phi=59^{\circ}\end{array}$ \\
\hline \multirow{2}{*}{ TLD-03 } & 1 & $\begin{array}{c}100 \text { to } 200 \mathrm{KPa} \\
15^{\circ} \text { to } 25^{\circ}\end{array}$ & $0.05 \mathrm{MPa}$ & $\begin{array}{l}\left.37^{\circ} \text { (family } 1\right) \\
\left.47^{\circ} \text { (family } 2\right) \\
\left.26^{\circ} \text { (family } 3\right)\end{array}$ & $\begin{array}{c}\mathrm{m}_{\mathrm{b}}=0.689 \\
\mathrm{~s}=0.000137 \\
\mathrm{a}=0.544 \\
\mathrm{c}=0.129 \mathrm{MPa} \\
\phi=43^{\circ}\end{array}$ & $\begin{array}{c}\mathrm{m}_{\mathrm{b}}=1.33 \\
\mathrm{~s}=0.001 \\
\mathrm{a}=0.5 \\
\mathrm{c}=0.215 \mathrm{MPa} \\
\phi=49^{\circ}\end{array}$ \\
\hline & 2 & $\begin{array}{c}200 \text { to } 300 \mathrm{KPa} \\
25^{\circ} \text { to } 35^{\circ}\end{array}$ & $0.086 \mathrm{MPa}$ & $\begin{array}{l}\left.45^{\circ} \text { (family } 1\right) \\
\left.45^{\circ} \text { (family } 2\right) \\
\left.34^{\circ} \text { (family } 3\right)\end{array}$ & $\begin{array}{c}\mathrm{m}_{\mathrm{b}}=1.683 \\
\mathrm{~s}=0.002 \\
\mathrm{a}=0.508 \\
\mathrm{c}=0.189 \mathrm{MPa} \\
\phi=56^{\circ}\end{array}$ & $\begin{array}{c}\mathrm{m}_{\mathrm{b}}=2.59 \\
\mathrm{~s}=0.008 \\
\mathrm{a}=0.5 \\
\mathrm{c}=0.322 \mathrm{MPa} \\
\phi=58^{\circ}\end{array}$ \\
\hline
\end{tabular}

3.8 $\mathrm{MPa}$. The roughness angle of discontinuities was measured in the field. The friction angle of the discontinuities was estimated through the equation proposed by Barton (2002). To obtain the residual friction angle of discontinuities in Barton and Bandis criterion, the roughness angle was subtracted from the friction angle. The results were $27^{\circ}$ and $33^{\circ}$ for family 1 and 3 , respectively.

\section{STABILITY ANALYSES}

Calibration of the strength parameters obtained from the correlation equations was done by stability analyses of failures observed in slopes. TLD02 presents block toppling occurrence, probably during the railway construction. Actually the slope is stable, according to observations in the field. TLD-03 presents two types of failures. In sector 1 an approximate circular failure was observed and in sector 2 a wedge failure was noticeable.

Mohr-Coulomb and Barton and Bandis criteria were used in the analysis of the TLD-02. In case of the Mohr-Coulomb criterion, the value used for the cohesion is zero, since infilling material is absent or has very small thickness. The friction angle of the toppling discontinuity is $45^{\circ}$ and for the basal discontinuity it is $35^{\circ}$. These values were obtained through the equation proposed by Barton (2002), see Table IX. The stability analysis using Mohr-Coulomb criterion returned incompatible values for the safety factor; they were below 1 . However, the analysis using the Barton and Bandis criterion returned an acceptable result. Factor of safety obtained was 1.754 with $50 \%$ of water; that condition was considered representative for this slope. The analysis was made using RocTopple software v.1 from Rocsience Inc. (2014). Table X shows the geometric data of the slope and Figure 2 shows the stability analysis results.

For analysis of the circular failure in the sector 1 of the TLD-03 slope, Slide v.6 from Rocscience Inc. (2010) was used. Sensitivity analyses were made to determine the position of the water table at the time of the failure. The minimum and maximum positions of water tables were defined using abacuses proposed by Hoek and Bray (1981) for a very raining period. This decision was taken 
TABLE X

Geometric data of the slope failure.

\begin{tabular}{cccc}
\hline \multicolumn{2}{c}{ Slope } & \multicolumn{2}{c}{ Toppling joint } \\
\hline Height & 5.0 meters & Spacing & 0.44 meters \\
Dip & $88^{\circ}$ & Dip & $48^{\circ}$ \\
$\begin{array}{c}\text { Inclination } \\
\text { of the top } \\
\text { plan }\end{array}$ & $0^{\circ}$ & $\begin{array}{c}\text { Overall base } \\
\text { inclination }\end{array}$ & $\begin{array}{c}47^{\circ}-67^{\circ} \\
\text { (range for } \\
\text { variation) }\end{array}$ \\
\hline
\end{tabular}

based on the knowledge that the failure occurred in a very raining period. Figure 3 shows the geometry of the slope and the locations of minimum $\left(\mathrm{W}_{\min }=\right.$ $0)$, maximum $\left(\mathrm{W}_{\max }=1\right)$ and medium $\left(\mathrm{W}_{\text {mean }}\right)$ water table, generated by Slide.

The strength criterion of Hoek and Brown was used for the analysis. The strength parameters were obtained through GSI and RMi, see Table IX. The analysis considering the strength values obtained by GSI yielded conservative results comparing to the analysis using the RMi strength estimates (Figure 4). A factor of safety equal 1 was obtained for $\mathrm{W}_{\text {min }}$ in case of GSI and equal 1 for $\mathrm{W}_{\max }$ in case of RMi. Both situations are related to high degrees of saturation.

The values of the cohesion and friction angle of the rock mass obtained from correlation with the parameters of the Hoek-Brown criterion returned an incompatible factor of safety value equal 4.3 and 7.2, using GSI and RMi, respectively.

In case of the stability analysis of the wedge failure in sector 2 of the TLD-03 slope, Swedge v.6 software from Rocscience Inc. (2006) was used. Table XI shows the geometric data of the slope and discontinuities, measured in failure surface.

The strength criterion used was the MohrCoulomb. Cohesion was considered null because filling material is absent and friction angle equal to 34 , obtained through the equation suggested

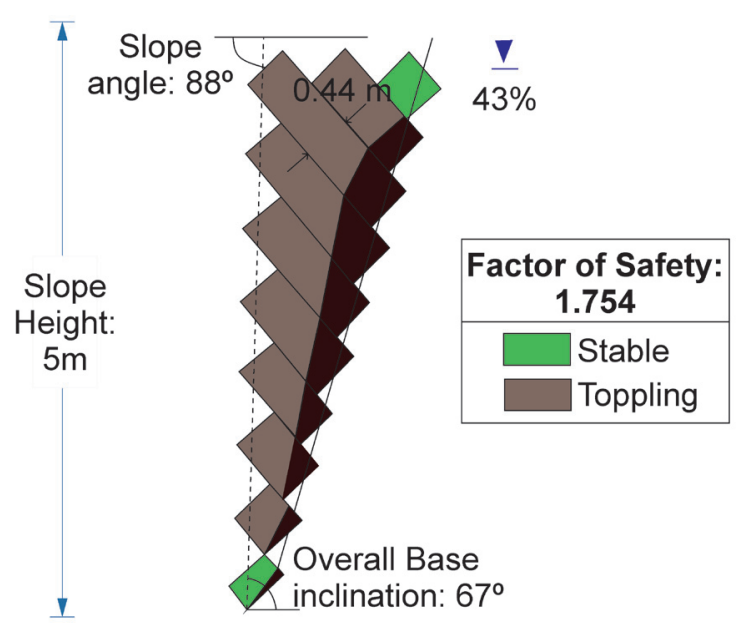

Figure 2 - Stability analysis in RocTopple.

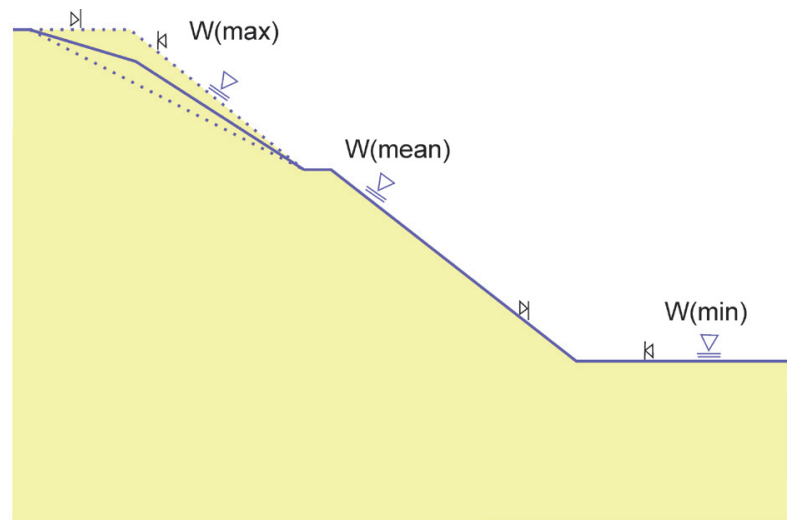

Figure 3 - Geometry of the slope and locations of minimum (Wmin), maximum (Wmax) and medium (Wmean) water tables.

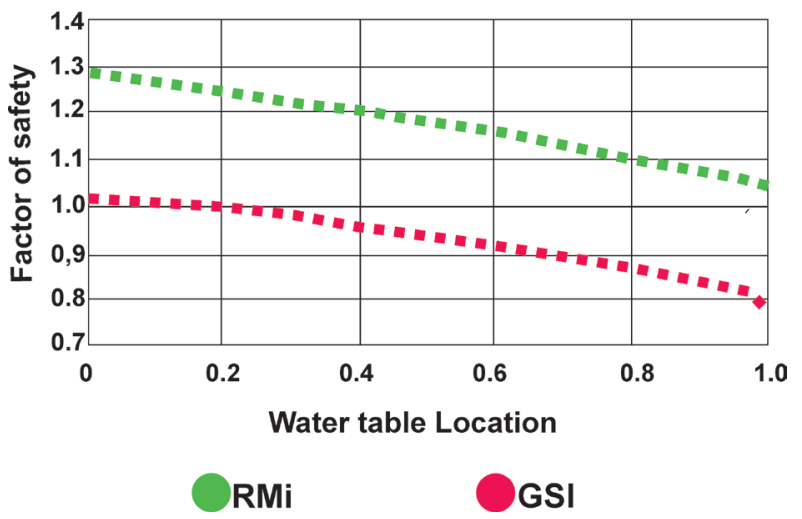

Figure 4 - Sensibility analyses of the water table location. 
TABLE XI

Geometric data of the slope and discontinuities.

\begin{tabular}{ccc}
\hline Wedge height & $\begin{array}{c}\text { Dip / Dip direction } \\
\text { of the slope }\end{array}$ & $\begin{array}{c}\text { Inclination of the } \\
\text { upper face }\end{array}$ \\
\hline $7.2 \mathrm{~m}$ & $226 / 52$ & $0^{0}$ \\
Dip / Dip & Family 1 & Family 3 \\
direction of the & $164 / 68$ & $314 / 75$ \\
discontinuities & 0 & $34^{\circ}$ \\
\hline
\end{tabular}

by Barton (2002), see Table IX. The percentage of saturation varied until a safety factor of 1 was obtained. This occurred when the saturation reached $100 \%$. Figure 5 shows the analysis result and the wedge geometry.

\section{DISCUSSION}

The degree of weathering is a huge obstacle in the geotechnical survey. Visibility of discontinuities is hampered by weathering; it happened during field survey in the sector 1 of the TLD-03 slope. In the TLD-01 geological structures are more clearly defined, facilitating the data survey.

The point load test proved to be applicable in TLD-01 and TLD-02 slopes and provided uniaxial compressive strength values within the range obtained through the geological hammer test. The Schmidt hammer test provided values with relatively large deviation from the average values. These values do not fall in the ranges suggested by the geological hammer test; they were very high. Therefore, it can be concluded the use of Schmidt hammer should be avoided in soft rocks. Geological hammer test proved to be a simple and effective method for estimating the uniaxial compressive strength.

The RQD depends of the scanline direction and the cutoff considered. Since the RQD is an index used in most of geomechanical classification systems, such as RMR and Q, uncertainties can be introduced in evaluation of rock mass quality.

RMR, GSI and Q systems proved to be easier to apply in the rock masses. Especially the GSI system,
Factor of Safety: 1.0877

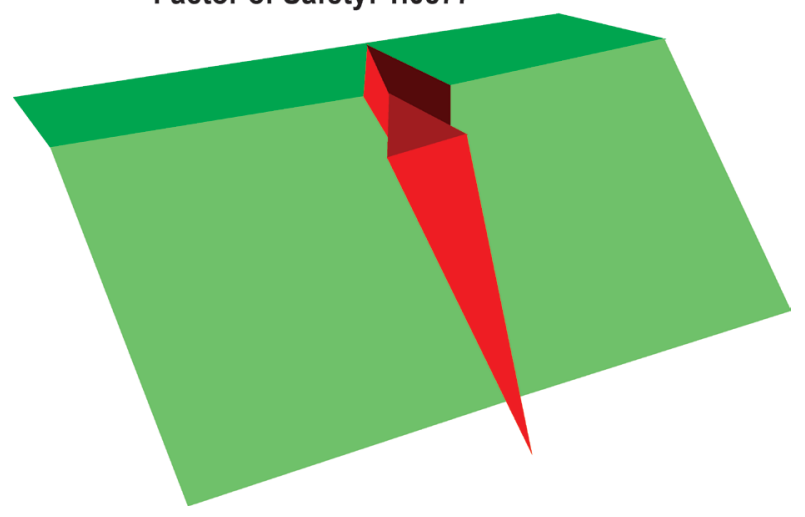

Figure 5 - Stability analysis result and wedge geometry in sector 2 of the TLD-03 slope.

which considers only two visual characteristics of the rock masses, the structure and the nature of the discontinuity surfaces. Among the geomechanical classification systems, the RMi is more reliable, once description of discontinuity parameters at the field permits an objective evaluation of them.

All the geomechanical classifications showed that the rock mass of TLD-03 is different from other rock masses studied. This is noticeable especially in sector 1 , where the weathering degree is very high.

As expected, the RMi is the classification which best caught the differences between the sectors considered, even in TLD-01, as demonstrated by the value in sector 4 , which is significant higher than the others. Another advantage of RMi is the fact that it has a clear physical meaning, as it represents the compressive strength of the rock mass. It could be seen that the compressive strength of the rock mass of sector 1, TLD-03, is many times smaller compared to the other rock masses studied. In case of sector 2, TLD-03, the difference in strength compared to TLD-02 and TLD-03 is clear. Moreover, the compressive strength of quartzite in TLD-01 is somewhat higher than the schists in other slopes.

Hoek and Brown criterion (2002) proved to be the best tool for determining the strength 
of the rock mass in TLD-03, sector 1. Cohesion and friction angle obtained through correlation equations with the Hoek and Brown criterion were not compatible, because maximum $\sigma_{3}$ (Table II) leaded to unreasonable values of shear strength of the rock mass. The introduction of slope height in $\sigma_{3}$ equation yielded illogical values of cohesion and friction angle, precluding the use of MohrCoulomb criterion.

Estimates of the rock mass strength by Hoek and Brown criterion provided by GSI yielded better results for the stability analysis of the circular failure in sector 1 of TLD-03 slope than the ones yielded by RMi (Figure 5), because the safety factor for some analyses with high degree of saturation using RMi was 1.3.

Table I, proposed by Bieniawski (1989), which correlates classes of the RMR with cohesion and friction angle of the rock masses, provided realistic values. However, the equation proposed by Barton (2002) for cohesion of the rock masses provided illogical results.

The equation for estimating the friction angle of discontinuities, proposed by Barton (2002), generated very high values in TLD-01 and TLD-02, see Table VII. In this study the Barton and Bandis criterion proved to be more effective for TLD-02, as demonstrated by stability analysis results.

In case of planar discontinuities, tilt tests may be a better alternative for estimating the friction angle of the discontinuity, instead of Barton proposal.

\section{CONCLUSIONS}

Geomechanical classifications are widely used to obtain the mechanical properties of the rock masses. However, the subjectivity in geomechanical classification systems could lead to propagation of errors. This propagation of errors influences the variability of the results of classifications. In addition, correlation equations for determining mechanical properties of rock masses could produce unreliable results.

In general, the use of the equations which provided the cohesion of the rock mass and friction angle of the discontinuity, proposed by Barton (2002) and the equations which related the cohesion and friction angle with the criterion of Hoek and Brown have not produced compatible results, as demonstrated in this paper.

As demonstrated in this paper, stability analyses continue to be an interesting way to calibrate strength parameters of rock masses and discontinuities.

\section{ACKNOWLEDGMENTS}

The authors acknowledge the Federal University of Ouro Preto, Programa de Pós-Graduação em Engenharia Mineral (PPGEM) and Coordenação de Aperfeiçoamento de Pessoal de Nível Superior (CAPES) for the support of this study.

\section{REFERENCES}

ASTM - AMERICAN SOCIETY FOR TESTING AND MATERIALS. 2001. Standard test method for determination of rock hardness by rebound hammer method. ASTM Stand, 2001, 5 p.

AYDIN A AND BASU A. 2005. The Schmidt hammer in rock material characterization. Eng Geol 81(1): 1-14.

BARTON N. 1978. Suggested methods for the quantitative description of discontinuities in rock messes. Int J Rock Mech Min Sci 15(6): 319-368.

BARTON N. 2002. Some new Q value correlations to assist in site characterization and tunnel design. Int J Rock Mech Min Sci 39(2): 185-216.

BARTON N AND BANDIS S. 1982. Effects of Block Size on the Shear Behavior of Jointed Rock. In: Proceedings of 23rd US Symposium of Rock Mechanics, Berkeley, California, p. 739-760.

BARTON N, LIEN R AND LUNDE J. 1974. Engineering classification of rock masses for the design of rock support. Rock Mechanics 6(4): 189-236.

BASU A AND KAMRAN M. 2010. Point load test on schistose rocks and its applicability in predicting uniaxial compressive strength. Int J Rock Mech Min Sci 47(5): 823-828. 
BIENIAWSKI ZT. 1989. Engineering rock mass classifications: a complete manual for engineers and geologists in mining, civil, and petroleum engineering. New York: J Wiley \& Sons, New York, USA, 271 p.

GOODMAN RE AND BRAY JW. 1976. Toppling of rock slopes. In: American Society of Civil Engineers. Proceedings of the specialty conference rock engineering for foundations and slopes, Boulder, Colorado, p. 201-234.

GRIMSTAD E AND BARTON N. 1993. Updating the Q-system for NMT. In: Norwegian Concrete Association. Proceedingf of Int. Symp. on Sprayed Concrete, Fagernes, Oslo, 22 p.

HOEK E. 1994. Strength of rock and rock masses. ISRM News Journal 2(2): 4-16.

HOEK E AND BRAY J. 1981. Rock Slope Engineering. Inst. Mining and Metallurgy, London.

HOEK E, CARRANZA-TORRES E AND CORKUM B. 2002. Hoek-Brown failure criterion - 2002 edition. Rocscience Publishing. https://www.rocscience.com/documents/hoek/ references/H2002.pdf. Accessed 11 July 2015.

ISRM. 1981. Rock Characterization Testing and Monitoring. New York: Oxford, 211 p.

ISRM. 2007. The complete ISRM suggested methods for rock characterization, testing and monitoring: 1974-2006. R. Ulusay \& J.A. Hudson, Ankara.

PALMSTRÖM A. 1982. The volumetric joint count - a useful and simple measure of the degree of jointing. In:
Proceedings of IV Int. Congress IAEG, New Delhi, p. 221228.

PALMSTRÖM A. 1995. RMi - a rock mass characterization system for rock engineering purposes. $\mathrm{PhD}$ Thesis, Oslo University, $400 \mathrm{p}$.

PALMSTRÖM A. 1996. Characterizing rock masses by the RMi for use in practical rock engineering, part 2: Some practical applications of the rock mass index (RMi). Tunnelling and Underground Space Technology 11(3): 287-303.

ROCSIENCE INC. 2006. Swedge Version 6.0 - 3D Surface Wedge Analysis for Slopes. www.rocscience.com, Toronto, Ontario, Canada.

ROCSIENCE INC. 2010. Slide Version 6.0 - 2D Limit Equilibrium Slope Stability Analysis. www.rocscience. com, Toronto, Ontario, Canada.

ROCSIENCE INC. 2014. RocTopple Version 1.0 - Toppling Analysis of Rock Slopes. www.rocscience.com, Toronto, Ontario, Canada.

SHALABI IF, CORDING EJ AND AL-HATTAMLEH OH. 2007. Estimation of rock engineering properties using hardness tests. Eng Geol 90(3): 138-147.

SINGH VK AND SINGH DP. 1993. Correlation between point load index and compressive strength for quartzite rocks. Geotech Geol Eng 11(4): 269-272. 